\title{
Cyclic Voltammetric Studies on Metal-organic Complexes Containing Piperidin-4-one thiosemicarbazones
}

\author{
K. Selvaraj' and M. Sujatha ${ }^{2 *}$ \\ 'Department of Chemistry, PSG College of Arts \& Science, Coimbatore-641018, Tamilnadu, India \\ 2Department of Chemistry, Chikkanna Government Arts College, Tirupur-641 602, \\ Tamilnadu, India; sensujatha@ yahoo.co.in
}

\begin{abstract}
Six cerium(III) nitrate complexes with variously substituted 2,6-diphenylpiperidin-4-one thiosemicarbazones have been prepared and characterized by elemental analyses, molecular weight determinations, molar conductance, IR, magnetic, cyclic voltammetric and thermal studies. Generally, cerium(III) may be easily converted to cerium(IV). In order to ascertain the oxidation state of the cerium in the prepared complexes, the cyclic voltammetric studies have been carried out. It has been observed that increase of potential produces an anodic peak in both the complexes. This indicates that the complexes are getting oxidized which consequently means that they were in the reduced form initially. Thus it is confirmed that cerium is present in +3 oxidation state in its complexes. This is further supported by the studies on concentration effect and sweep rate. Based on the above observations, 10-coordinated structure has been proposed for the complexes.
\end{abstract}

Keywords: 10-coordinated Structure, Cerium(III) Nitrate Complexes, Piperidin-4-one Thiosemicarbazones, Thiosemicarbazone Complexes

\section{Introduction}

The fields of coordination chemistry have attracted increasing interest in recent years not only from a structural point of view, but also owing to their potential applications in catalysis, medicine, sorption, electrical conductivity, magnetism and photochemistry. The coordination chemistry of nitrogen-sulphur donor chelating agents has mainly been studied with transition metals [1]-[7]. During the last decade, groupIV transition metal chemistry has made a major contribution in providing effective complexes for novel metal assisted organic transformations [8], [9]. Recently it has been reported that the metal complexes of ligands possess a wide variety of biological activities[10]. Cerium(IV) has been used as an oxidizing agent and an analytical reagent, especially in acid media [11]-[15]. The cocrystallization of $\mathrm{Ce}_{2}\left(\mathrm{SO}_{4}\right)_{3}$ and
$\mathrm{La}_{2}\left(\mathrm{SO}_{4}\right)_{3}$ in aqueous and $\mathrm{H}_{2} \mathrm{SO}_{4}\left(150 \mathrm{~g} / \mathrm{dm}^{3}\right)$ solutions at $25^{\circ} \mathrm{C}$ and $64^{\circ} \mathrm{C}$ is studied [16]. Thiosemicarbazones have received more attention as they possess a wide spectrum of medicinal properties [17]-[21] including activity against bacterial, tuberculosis, leprosy, viral infections, psoriasis, rheumatism, trypanosomiasis, coccidiosis and malaria. In most of the complexes studied, thiosemicarbazone function coordinates to the metal ion in the cis configuration as a bidentate ligand bonding through thione/thiol sulphur atom and the imino nitrogen atom in a bidentate manner, resulting in the formation of a five membered chelate ring. In recent years, thiosemicarbazones have been used as analytical reagents for the determinations of metal ions [22]-[32] using different physico-chemical techniques. An excellent review [33] is available in the literature which deals with the analytical potentialities of thiosemicarbazones.

${ }^{*}$ Author for correspondence 


\section{Experimental}

\subsection{Materials and Methods}

Six cerium(III) nitrate complexes with variously substituted 2,6-diphenylpiperidin-4-one thiosemicarbazones have been prepared.

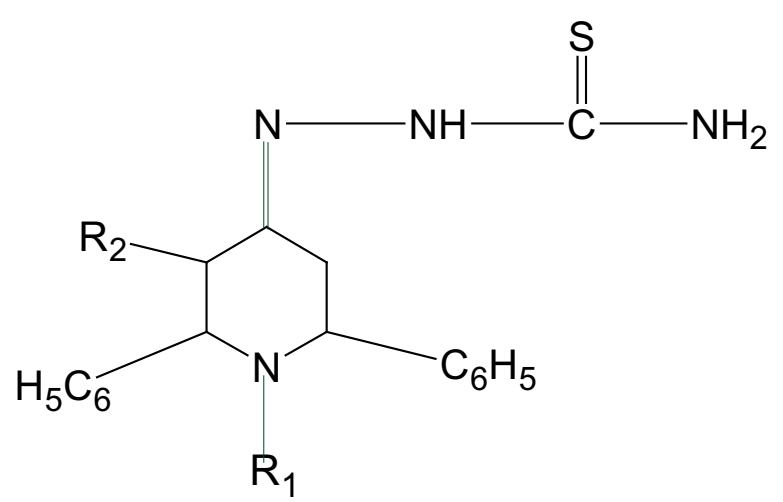

Table 1. Preparation of ligands

\begin{tabular}{lll}
\hline Ligands & $\mathrm{R}_{1}$ & $\mathrm{R}_{2}$ \\
\hline$\left(\mathrm{L}^{1}\right)$ & $\mathrm{H}$ & $\mathrm{H}$ \\
$\left(\mathrm{L}^{2}\right)$ & $\mathrm{H}$ & $\mathrm{CH}_{3}$ \\
$\left(\mathrm{~L}^{3}\right)$ & $\mathrm{H}$ & $\mathrm{C}_{2} \mathrm{H}_{5}$ \\
$\left(\mathrm{~L}^{4}\right)$ & $\mathrm{CH}_{3}$ & $\mathrm{H}$ \\
$\left(\mathrm{L}^{5}\right)$ & $\mathrm{CH}_{3}$ & $\mathrm{CH}_{3}$ \\
$\left(\mathrm{~L}^{6}\right)$ & $\mathrm{CH}_{3}$ & $\mathrm{C}_{2} \mathrm{H}_{5}$ \\
\hline
\end{tabular}

Table 2. Piperidin-4-ones used for ligand preparation

\begin{tabular}{lll}
\hline Piperidinone & $\mathrm{R}_{1}$ & $\mathrm{R}_{2}$ \\
\hline$\left(\mathrm{P}^{1}\right)$ & $\mathrm{H}$ & $\mathrm{H}$ \\
$\left(\mathrm{P}^{2}\right)$ & $\mathrm{H}$ & $\mathrm{CH}_{3}$ \\
$\left(\mathrm{P}^{3}\right)$ & $\mathrm{H}$ & $\mathrm{C}_{2} \mathrm{H}_{5}$ \\
$\left(\mathrm{P}^{4}\right)$ & $\mathrm{CH}_{3}$ & $\mathrm{H}$ \\
$\left(\mathrm{P}^{5}\right)$ & $\mathrm{CH}_{3}$ & $\mathrm{CH}_{3}$ \\
$\left(\mathrm{P}^{6}\right)$ & $\mathrm{CH}_{3}$ & $\mathrm{C}_{2} \mathrm{H}_{5}$ \\
\hline
\end{tabular}

\subsection{Preparation of the Ligands}

The 2,6-diphenylpiperidin-4-one thiosemicarbazones $\left(\mathrm{L}^{1}\right)$ $\left(L^{6}\right)$ were prepared from the corresponding piperidin4-ones $\left(\mathrm{P}^{1}\right)-\left(\mathrm{P}^{6}\right)$. Thiosemicarbazide dissolved in hot methanol was added to a solution of $\mathrm{r}$-2,c-6-diphenylpi- peridin-4-one $\left(\mathrm{P}^{1}\right)$ in the same solvent. A few drops of concentrated hydrochloric acid was added and the reaction mixture was refluxed for $4 \mathrm{~h}$ and cooled. The product formed was filtered off and washed with hot methanol. Crystallisation of the product from methanol gave 2,6-diphenylpiperidin-4-one thiosemicarbazones.

\subsection{Preparation of Metal Complexes}

A mixture of metal salt in ethanol was added to a solution of 2,6-diphenylpiperidin-4-one thiosemicarbazones in ethanol and refluxed. The solvent was then distilled off under reduced pressure. The residue was repeatedly washed with hot ethanol and ether to remove the unreacted metal salt and the ligand. The product was dried.

Table 3. Preparation of metal complexes

\begin{tabular}{lll}
\hline Metal salt used & Complexes & $\begin{array}{l}\text { Respective } \\
\text { Ligands used }\end{array}$ \\
\hline $\begin{array}{l}\text { Cerium(III) } \\
\text { nitrate }\end{array}$ & $\left(\mathrm{Ce}^{1}\right)-\left(\mathrm{Ce}^{6}\right)$ & $\left(\mathrm{L}^{1}\right)-\left(\mathrm{L}^{6}\right)$ \\
\hline
\end{tabular}

These complexes are non-hygroscopic dark green solid and are stable in air. They are soluble in DMSO, DMF and acetonitrile and insoluble in water and ether.

\section{Results and Discussion}

\subsection{Cyclic Voltammetric Studies}

Cyclic voltammetry is the most widely used technique for acquiring qualitative information about electrochemical reactions. The characteristic shapes of the voltammetric wave and their unequivocal position on the potential scale virtually finger print the individual electrochemical properties of the redox systems and for this reason the method has been labelled electrochemical spectroscopy. The power of cyclic voltammetry results from its ability to rapidly provide considerable information on the thermodynamics of redox processes and the kinetics of heterogeneous electron-transfer reactions and on coupled chemical reactions or adsorption processes. Cyclic voltammetry is often the first experiment performed in an electroanalytical study. In particular, it offers a rapid location of redox potentials of the electroactive species and convenient evaluation of the effect of media upon the 
redox process. In the cyclic voltammetric experiment, a potentiostat together with three electrode cells are used. In this arrangement, the current passes between the working electrodes and the counter electrode. The potential of the working electrode is measured relative to a separate reference electrode.

The voltammogram is a display of current versus potential obtained by measuring the current at the working electrode during the potential scan. In $\mathrm{CV}$, if the electron transfer process of a redox system is fast compared to the other processes like diffusion, the reaction is said to be electrochemically reversible. Modern instruments have the flexibility of the wide choice of switching potentials at different scan rates. A variation in scan rate can lead to additional information. Thus in cyclic voltammetry, the fate of the electrode species produced in the forward scan is probed in the backward scan which helps to find whether the equilibrium is reversible, quasi reversible or irreversible. The cyclic voltammetric methods have been used for numerous basic studies of electrochemical systems.

In the present investigation, cerium(III) nitrate complexes $\left(\mathrm{Ce}^{1}\right)-\left(\mathrm{Ce}^{6}\right)$ have been prepared using cerium(III)nitrate. Generally, cerium(III) may be easily converted to cerium(IV). So inorder to ascertain the oxidation state of the cerium in the prepared complexes $\left(\mathrm{Ce}^{1}\right)-\left(\mathrm{Ce}^{6}\right)$, the cyclic voltammetric studies have been carried out. These studies were done by using BAS IM6 Potentiostat, using TBATFB (tetrabutyl ammonium tetraflouroborate) as supporting electrolyte and acetonitrile as the solvent. The cathode is glassy carbon (working electrode), which identifies the oxidation state of the compound and anode is platinum foil (counter electrode) that measures the current. $\mathrm{Ag} / \mathrm{Ag}^{+}$is the reference electrode to measure the potential variation. The studies were carried out for the complexes $\left(\mathrm{Ce}^{1}\right)$ and $\left(\mathrm{Ce}^{6}\right)$ in $5 \mathrm{mM}$ and $10 \mathrm{mM}$ solutions at room temperature. It has been observed that increase of potential produces an anodic peak in both the complexes. This indicates that the complexes are getting oxidized which consequently means that they were in the reduced form initially. Thus it is confirmed that cerium is present in +3 oxidation state in its complexes $\left(\mathrm{Ce}^{1}\right)$ and $\left(\mathrm{Ce}^{6}\right)$. This is further supported by the studies on concentration effect and sweep rate.

$$
\mathrm{Ce}^{3+} \rightarrow \mathrm{Ce}^{4+}+\mathrm{e}^{-}
$$

The concentration effect and sweep rate effect of the complexes are given in the Figures 1-4.

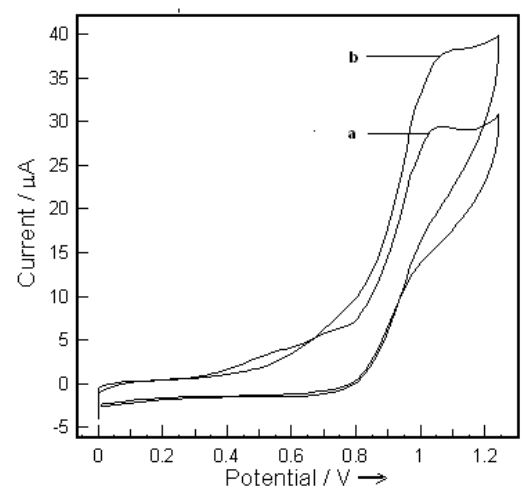

Figure 1. Concentration effect of complex $\left(\mathrm{Ce}^{1}\right)$ a) $5 \mathrm{mM}$ b) $10 \mathrm{mM}$.

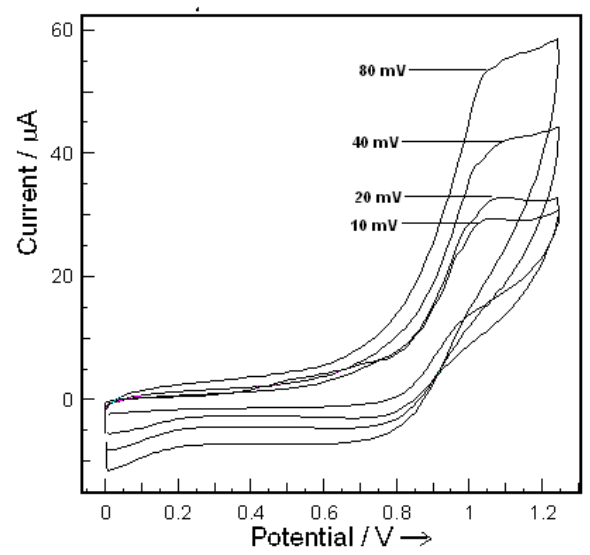

Figure 2. Sweep rate effect of complex $\left(\mathrm{Ce}^{1}\right)-10,20,40$ and $80 \mathrm{mV} / \mathrm{s}$.

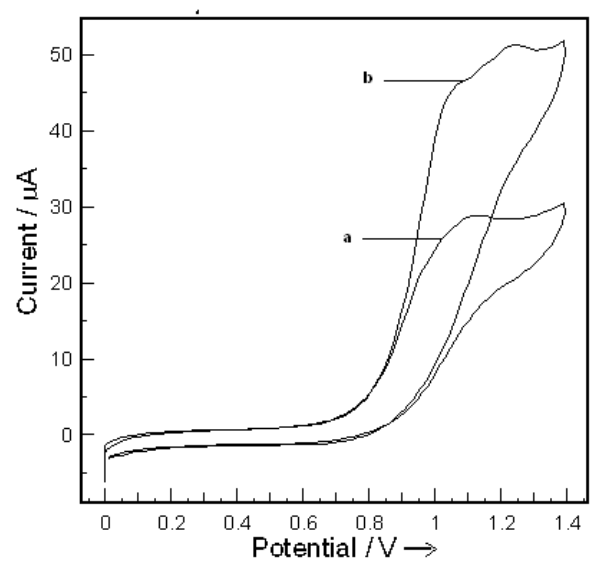

Figure 3. Concentration effect of complex $\left(\mathrm{Ce}^{6}\right)$ a) $5 \mathrm{mM}$ b) $10 \mathrm{mM}$. 


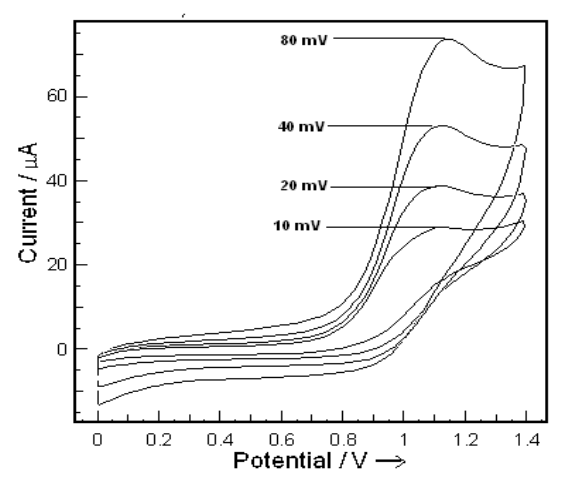

Figure 4. Sweep rate effect of complex $\left(\mathrm{Ce}^{6}\right)$ 10, 20, 40 and $80 \mathrm{mV} / \mathrm{s}$.

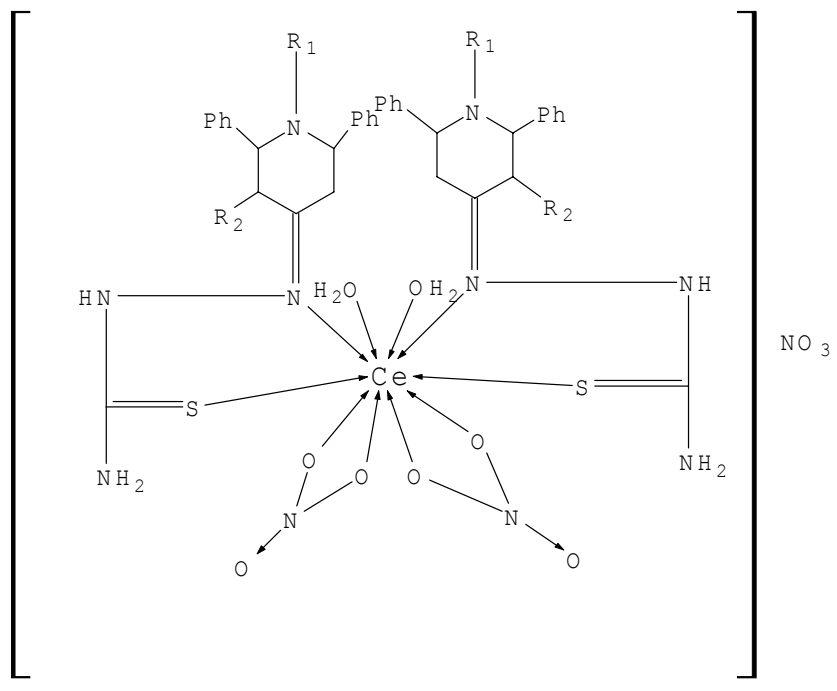

Figure 5. Structure of cerium(III) nitrate $\left(\mathrm{Ce}^{1}\right)-\left(\mathrm{Ce}^{6}\right)$.

\section{Conclusions}

Cyclic voltammetric studies reveal that the cerium ion in the complexes is in $\mathrm{Ce}^{3+}$ state. All the experimental observations lead to the formulation of 10-coordinated structure (Figure 5) for these complexes.

\section{References}

1. Ali M.A., and Livingstone S.E., "Metal complexes of sulphur -nitrogen chelating ligands," Coord. Chem. Rev., vol. 13, pp. 101-132, Aug. 1974.

2. Ali M.A., and Bose R., "Metal complexes of schiff bases formed by condensation of 2-methoxybenzaldehyde and 2-hydroxybenzaldehyde with S-benzyldithiocarbazate," J. Inorg. Nucl. Chem., vol. 39, pp. 265-269, May 1977.

3. Ali M.A., and Tarafder M.T.H., "Metal complexes of sulphur and nitrogen-containing ligands: Complexes of s-benzyldithiocarbazate and a schiff base formed by its condensation with pyridine-2-carboxaldehyde," J. Inorg. Nucl. Chem., vol. 39, pp. 1785-1791, May 1977.

4. Tarafder M.T.H., and Ali M.A., "Chelates of Nickel (II) and Copper (II) with tridentate Schiff base formed by the condensation of S-benzyldithiocarbazate with benzoin," Can.J. Chem., vol. 56, pp. 2000-2002, 1978.

5. Ali M.A., Hossain G., Majumder S.M.M.H., Uddin M.N., and Tarafder M.T.H., "Synthesis and characterization of some new nickel(II), zinc(II) and cadmium(II) complexes of quadridentate SNNS ligands," Polyhedron, vol. 6, pp. 1653-1656, Apr. 1987.

6. Tarafder M.T.H., and Rahim M., "Nickel(II) complexes of S-benzyl- $\beta$ - $N$-(furyl)methylenedithiocarbazate," Indian J. Chem., vol. 28A, pp. 1105, 1989.

7. Ali M.A., Haroon C.M., Uddin M.N., Majumder S.M.H., Tarafder M.T.H., and Khair M., "Synthesis, characterization and biological activities of some new nickel(II), zinc(II) and cadmium(II) complexes of quadridentate SNNS ligands", Transition Met. Chem., vol. 17, pp. 133-136, Apr. 1992.

8. Erker G., and Pefaft R., "Developing an organometallic (butadiene)bis(cyclopentadienyl)zirconium-basedtemplate synthesis for the preparation of stable conjugated primary enamines," Organometallics, vol. 12, pp. 1921-1926, May 1993.

9. Negishi E.I., and Takahashi T., "Patterns of Stoichiometric and Catalytic Reactions of Organozirconium and Related Complexes of Synthetic Interest," Accounts Chem. Res., vol. 27, pp.124-130, May 1994.

10. Das M., and Livingstone S.E., "Cytotoxic action of some transition metal chelates of Schiff bases derived from S-methyldithiocarbazate," Br. J. Cancer, vol. 37, pp. 466-469, March 1978.

11. Richardson W.H., Ceric Ion Oxidation of Organic Compounds in Oxidation in Organic Chemistry, Part A, K.B. Wiberg Ed. New York and London: Academic Press, 1965, pp.271-272.

12. Moore J.W., and Anderson R.C., "Kinetics of the Reaction

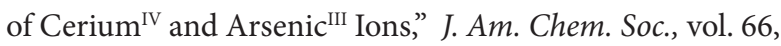
pp. 1476-1479, Sep. 1944.

13. Chimatadar S.A., Nandibewoor S.T., Sambrani M.I., and Raju J.R., "Chromium(III)-catalysed cerium(IV) oxidation of arsenic(III) in aqueous sulphuric acid," J. Chem. Soc. Dalton Trans., Issue 3, pp. 573-577, 1987.

14. Chimatadar S.A., Koujalagi S.B., and Nandibewoor S.T., "Kinetics and mechanism of palladium (II) catalyzed chromium (VI) oxidation of mercury (I) in aqueous sulphuric acid ", Trans. Met. Chem., vol. 26, pp. 662-667, Dec. 2001.

15. Chimatadar S.A., Basavaraj T., and Nandibewoor S.T., "Ruthenium(III) Mediated Cerium(IV) oxidation of Thallium(I) in aqueous sulphuric Acid--a kinetic and mechanistic study," Inorg. React. Mech., vol. 4, pp. 209-219, 2002.

16. Milanova M.M., Todorovsky D.S., Balarew C.C., Minkova N.L., Ivanova K.I., "Influence of complexation on the 
composition of equilibrium phases in the system of $\mathrm{Ce}_{2}\left(\mathrm{SO}_{4}\right)_{3}$ $\mathrm{La}_{2}\left(\mathrm{SO}_{4}\right)_{3}$ ”Cen. Eur. J. Chem., vol. 5(1), pp. 13-19, 2007.

17. Thompson R.L., Minton S.A. Jr., Officer E., and Hitchings G.H., "Effect of heterocyclic and other Thiosemicarbazones on vaccinia infection in the mouse", J. Immunol., vol. 70, pp. 229-234, 1953.

18. Jones D.H., Slack R., Squires S., and Wooldridge K.R.H., "Antiviral Chemotherapy-the activity of Pyridine and Quinoline derivatives against neurovaccinia in mice", J. Med. Chem., vol. 8, pp. 676-680, 1965.

19. Orloa N.N., Aksenova V.A., Sclidovkin D.A., Bogdanova N.S., and Perskhin G.N., "Spectrophotometric determination of Palladium with 3-Thiophenaldehyde-4-phenyl-3-thiosemicarbazone", Russ. Pharm. Toxicol., vol. 5 pp. 348-354, 1968.

20. Butler K., U.S. Patent No.3, 382, 266 (1968). 21. D.J.Bauer, L.St.Vincent, C.H.Kempe and A.W.Downe, "Prophylactic treatment of smallpox contacts with n-methylisatin $\beta$-thiosemicarbazone (compound 33t57, marboran)" Lancet, Vol. 282, pp.494-495,1963.

21. Nishoika H., Kumajai T. and Nagahiro T., "ExtractionSpectrophotometric determination of Palladium with 3-Thiophenaldehyde-4-phenyl-3-thiosemicarbazone" Microchem. J., vol. 50, pp. 88-93, 1994.

22. Singh R.B., Garg B.S., and Singh R.P., "Analytical applications of thiosemicarbazones and semicarbazones: A review", Talanta, vol. 25, pp. 619-632, 1978.

23. Rios A., and Valcarcel M., "Simultaneous kinetic determination of copper, cobalt and nickel by means of -- $\mathrm{C}=\mathrm{N}$ group interchange reactions", Talanta, vol. 32, pp. 851-858, 1985.

24. Ballesteros L., and Peterz- Bendito D., "Micro and surface analysis with fast heavy ions", Anal. Chim. Acta., vol. 195, pp. 169-172, 1992.
25. de Rodrigues J., Torres J., and Cano Pavon J.M., "Kinetic uncatalysed determination of copper based on its slow rate of complexation with 5,5-dimethyl-1,3-cyclohexanedione bis(4-phenyl-3-thiosemicarbazone)" Microchim. Acta., vol. 85, pp. 69-75, 1985.

26. Ozkhan E., and Atalay T., "Determination of thermodynamic parameters of some complexes of 9-ethyl-3-carbazolecarboxaldehyde 4-phenyl-3-thiosemicarbazone" Tr. J. of Chemistry, vol.18, pp. 120-127, 1994.

27. Ozkhan E., and Atalay T., "Thermodynamic studies of some complexes of 2-benzoylpyridine 4-phenyl-3- thiosemicarbazone", Chim. Acta Turcica, vol. 23, 49-52, 1995.

28. Ozkhan E., and Atalay T., "Thermodynamic studies of some complexes semicarbazones”, Tr. J. Chem., vol. 19, pp. 60-63, 1995.

29. Ballesteros L., and Perez-Bendito D., "Analytical use of the kinetics of complex formation: simultaneous determination of iron and cobalt by differential kinetic methods", Analyst, vol. 108, pp. 443-451, 1983.

30. Atalay T., and Akgemei E.G., "Determination of thermodynamic parameters of some complexes of thiosemicarbazone" Tr. J. Chem., vol. 22, pp. 123-127, 1998.

31. Singh R.B., Garg B.L., and Singh R.P., "A new catalytic reaction of rhenium and its analytical application", Talanta, vol. 25, pp. 389-393, 1975.

32. Reddy K.H., and Reddy D.V., "The transition metalhydrogen bond", Quat. Chem. Rev., Indian Council of Chemists, Agra, vol. 1, pp. 47-49, 1985.

33. Heinze J., Angew. "Cyclic voltammetry-“electrochemical spectroscopy”. New Analytical Methods". Chemie., vol. 23, pp. 831-847, 1984. 